словообразовательных особенностей, выделены восемь разновидностей синонимических групп синонимов, в состав которых вошли 159 синонимических пар исследуемой терминологии: иноязычный термин - немецкий термин (19\%), разнокоренные составные слова (17\%), однокоренные составные слова (14\%), термины-однословы многокомпонентные составные слова (13\%), немецкие разнокоренные синонимы (13\%), полное (немецкое или иноязычное) и сокращенное наименование (12\%), термины-композиты - терминологические сочетания (9\%), немецкие однокоренные синонимы - (3\%). Наибольший синонимический пласт в исследуемой терминологии составляют дублетные терминосинонимы иноязычного и немецкого происхождения. Это связано с заимствованием иностранных слов и искусственным образованием терминов на базе немецкого языка во избежание заимствований и создание собственных терминов. Рекомендуется в профессиональной речи избегать синонимических терминологических наименований и узаконивать только одно наименование. Определены перспективы дальнейших исследований лексико-семантической организации немецкоязычной терминосистемы в области робототехники.

Ключевые слова: термин, терминосистема робототехники, синоним, синонимия, синонимичные отношения.

Petrenko Oksana. Synonymous Relations of German-Speaking Terms in the Field of Robotics. The article investigates the phenomenon of synonymy of terms of the German language in the field of robotics on the material of 1670 language units, selected through a continuous sample of 16 professional sources (professional texts in robotics). The reasons that determine the need to study the synonymous relations of German-language terms of robotics, as well as subject, object, methods and tasks are outlined in this research. Two opposing views on the solution of the problem of terminological synonymy are considered in the article. The concept of synonym, doublet, synonymy, synonymous relations was identified. The comparative analysis of synonymous groups on semantic and structural levels is conducted. Most definitions of synonymy in general literary language are based on the proximity of the meaning of lexical units, terminological synonyms are defined as linguistic units, absolutely identical in meaning and interchangeable in any context, and the concept of "terminological synonymy" most adequately expresses the presence of several names for one meaning. In terms of origin, structural and word-forming features, eight varieties of synonymous groups of synonyms were distinguished, comprising 159 synonymous pairs of the studied terminology: foreign term - German term (19\%), mixed root words $(17 \%)$, common root words $(14 \%)$ ), single-word terms - multicomponent compound words (13\%), German mixed-root synonyms (13\%), full (German or foreign language) and abbreviated name (12\%), term-composites - terminological word combinations ( $9 \%$ ), German root synonyms - (3\%). The largest synonymic layer in the terminology under study is the doublet synonyms of foreign and German origin. This is due to the borrowing of foreign words and the artificial formation of terms based on the German language in order to avoid borrowing and to create their own terms. It is recommended to avoid synonymous terminological names in the professional language and legalize only one name. The prospects for further research of the lexical-semantic organization of the German-speaking term system in the field of robotics have been determined.

Key words: term, robotics terminology, synonym, synonymy, synonymous relations.

DOI: https://doi.org/10.32782/2410-0927-2020-12-25

УДК $821.161 .2(71)^{\prime} 06(092)$

Ольга Плєщкова, Ірина Калиновська, Еліна Коляда

\title{
ІСТОРІЯ РІДНОГО КРАЮ КРІЗЬ ПРИЗМУ ЖИТТЕВОГО І ТВОРЧОГО ШЛЯХУ УКРАЇНСЬКО-КАНАДСЬКОЇ ПИСЬМЕННИЦІ ЛЮБОВІ ВАСИЛІВ-БАЗЮК
}

У статті проаналізовано життєвий і творчий шлях Любові Йосипівни Василів-Базюк. Ім'я незламної жінки, родом із волинського села, добре відоме поза межами України. Під час Другої світової війни вона змушена була залишити рідну землю, щоб через десятиліття не раз повернутися сюди, довівши, що серце ії належить Батьківщині. Вона є прикладом сильної українки, яка зуміла залишитися вірною своєму народові.

Сьогодні Любов Василів-Базюк - відома письменниця, науковиця, благодійниця, справжня патріотка, яка, проживаючи за океаном, у Торонто, не пориває зв'язків із Волинню. Вона дбає про будівництво українських церков, організовує збір коштів на відбудову Волинської богословської семінарії, засновує іменні стипендії для студентів, пише книги про події, які є близькими для мільйонів українців.

У творчому і науковому доробку Любові Василів-Базюк, почесної професорки Волинського національного університету імені Лесі Українки, десятки наукових статей, віршів, дописів, десять історичних романів, які написані на основі документальних матеріалів, спогадів власних та очевидців. Наукові статті та романи авторки присвячені трагічним подіям в історії України та Волині зокрема. Письменниця також висвітлює важливі сучасні політичні події та соціальні проблеми життя українців як в Україні, так і в еміграції. Вона пише про своє життя, про те, що вплинуло на іiі характер та як формувалися іiі релігійні та політичні погляди. Любов Василів-Базюк постійно надсилає примірники своїх книг до українських університетів, коледжів, бібліотек.

(C) Плєшкова О., Калиновська I., Коляда Е., 2020 
За велику жертовну працю Любов Василів-Базюк нагороджена орденами Св. Варвари, Св. Миколая, Св. Кирила і Мефодія.

У 2019-2020 рр. життєвий і творчий шлях Любові Василів-Базюк досліджували науковці Волинського національного університету імені Лесі Українки та вчителі Ковельської міської гімназії імені Олени Пчілки в рамках грантового дослідницького проєкту за підтримки Канадського інституту українських студій (Меморіальний Фонд імені Петра Чорного). Було проведено низку творчих зустрічей, круглих столів, семінарів, науково-мистецьких заходів.

Ключові слова: Україна, Канада, Волинь, письменниця, українсько-канадські студії.

Постановка наукової проблеми та їі значення. Розповідати історію рідного краю водночас нелегко, але разом з тим необхідно. Це завжди підкреслює Любов Йосипівна ВасилівБазюк, почесна професорка Волинського національного університету імені Лесі Українки, яка нагороджена Золотим нагрудним знаком університету за багаторічну сумлінну працю, за особистий внесок у розвиток університету, за помітну роль у творенні сучасної вітчизняної літератури, за активну громадянську позицію [10]. Народжена на Волині, Любов Йосипівна була змушена покинути Україну в часи лихоліття Другої світової війни. Однак попри всі випробування долі вона стала лише сильнішою, і сьогодні $\epsilon$ відомою письменницею, яка проживає в Канаді (м. Торонто), але не пориває зв'язків з рідним краєм, з Волинню.

Наукові статті та романи авторки присвячені трагічним подіям в історії України та Волині зокрема, очевидицею багатьох 3 яких вона була. Їх вивчення необхідне у контексті дослідження правдивої української історії, а також для підвищення зацікавленості цією тематикою студентів, учнів, науковців, а в ширшому контексті - для привернення уваги дослідників до українсько-канадських студій. Актуальності нашої розвідки додає факт нещодавнього відзначення Любов’ю Василів-Базюк поважного ювілею, 90-річчя, з нагоди якого було проведено науково-мистецькі заходи у Волинському національному університеті імені Лесі Українки [10] та Ковельській міській гімназії імені Олени Пчілки [5].

Мета і завдання статті. Стаття має за мету схарактеризувати історію рідного краю крізь призму життєвого і творчого шляху Любові Василів-Базюк. Реалізація мети можлива за умови виконання таких завдань: 1) показати, як історія рідного краю відображена в життєписі Любові Василів-Базюк; 2) проаналізувати ії творчий доробок; 3) окреслити ії діяльність як письменниці, патріотки, науковиці, благодійниці.

Методи та методики дослідження. У процесі дослідження застосовувалися такі загальнонаукові методи, як індукція, дедукція, аналіз і синтез. Ми проаналізували низку публікацій про Любов Василів-Базюк в українській пресі, іiі виступи на конференціях, статті авторки, а також матеріали особистого листування з письменницею.

Результати та дискусії. Ім'я Любові Василів-Базюк добре знайоме українським канадцям, зокрема ії згадують як “плідного прозаїка", автора політико-історичних книг в дописі канадської онлайн-газети "Новий шлях" про розвиток української літератури в Канаді [11]. Огляд досліджуваних матеріалів показав, що біографію i творчість Любові Йосипівни висвітлено в Україні фрагментарно. “Ім'я Любові Василів-Базюк не достатньою мірою поціноване в Україні. У пошуковику Google щонайбільше знайдуться побіжні посилання на їі книги, які надійшли до фондів бібліотек, декілька відгуків вдячних читачів, проміжні згадування iii імені у контексті проведених заходів, а сторінка у Вікіпедії - скупа на факти з біографії, творчого доробку, просвітницької активності Любові Йосипівни як у Канаді, що стала їі другою Батьківщиною, так і в до щему дорогій іï серцю Україні” [6].

Більшість дописів в українській пресі присвячено анотаціям романів авторки, подякам від бібліотек та читачів за щедрі дарунки від письменниці, яка своїм коштом публікує і постійно надсилає примірники своїх книг до українських університетів, коледжів, семінарій, громадських бібліотек у різних куточках України.

Увагу привертає кілька публікацій в українській пресі, зокрема інтерв’ю Тетяни Костенко 3 Любов”ю Василів-Базюк в “Дзеркалі тижня” від 22 жовтня 2010 р. про те, як родина письменниці перебралася до Канади, про важке життя українських інтелігентів в Торонто, про особисте знайомство 3 митрополитом Іларіоном й Уласом Самчуком, про відкриття 22 серпня 2010 р. пам'ятника жертвам терору і депортації українців Холмщини у 1938-1947 рр., про 
єпископів родини Василів, про урочище Гурби і книгу “Не вір!”, а також про подорож письменниці Україною [4].

В інтерв'ю Романа Смілки з Любов'ю Василів-Базюк від 10 січня 2011 р. в "Народній правді" йдеться про відвідини авторкою фестивалю-конкурсу “Пісні незабутого краю”, присвяченого мистецтву Закерзоння у містечку Городок Львівської області, про коріння письменниці, про життя українців в Канаді, про написання романів, свою родину та про те, що найбільшою цінністю для кожної людини є свобода [8].

У розлогому дописі Олександра Панченка, адвоката з м. Лохвиця Полтавської області, в газеті “День” від 25 вересня 2019 р. викладено фрагменти листування з Любов’ю Василів-Базюк про трагічний шлях українського священства, про важку долю родичів, односельчан та знайомих письменниці, багато з яких є відомими в Україні, спогади про страшні часи переслідувань, репресій та страху [7].

Наукова стаття Тамари Бабійчук присвячена вивченню пропаганди художніх творів медіазасобами на заняттях української літератури і в позанавчальній роботі. Авторка досліджує медіатворчість на прикладі роману Любові Василів-Базюк “Крізь пекло на землі”, зокрема презентує тексти для відеороликів та матеріал для міні-екранізацій [1].

Комплексне дослідження життєвого i творчого шляху Любові Василів-Базюк здійснюється науковцями Волинського національного університету імені Лесі Українки та вчителями Ковельської міської гімназії імені Олени Пчілки в рамках грантового дослідницького проєкту за підтримки Канадського інституту українських студій Меморіального Фонду імені Петра Чорного [3]. Керівник проєкту - доцент ВНУ імені Лесі Українки Ірина Калиновська. Було проведено низку творчих зустрічей, круглих столів, семінарів, науково-мистецьких заходів, опрацьовано науковий та творчий доробок Любові Йосипівни, результатом якого $є$ публікація трьох тез доповідей на конференціях, двох наукових статей [3], [6] та розділу в колективній монографії 2020 р. “Канадознавство: соціальні та освітні візії” [2].

Отож народилася Любов Йосипівна Василів-Базюк 30 вересня 1929 р. в селі Видерта Камінь-Каширського району в сім'ї священника Йосипа, родом із Холмщини, та його дружини Єлизавети з Поділля. У родині письменниці було два єпископи, яких замордували більшовики, Амврозій та Анатолій. “Мій тато протоісрей Йосип Василів і вся батькова родина споконвіку родилися у містечку Тишівичі, щзо неподалік Туркович $і$ колишньої столиці Холмщчини Червна. Периу парафію тато отримав у с. Крупе біля Красноставу. Проте поляки забрали иеркву, а парафія стала приписним селом. Таким чином батько переїхав на Полісся, до села Видерта Камінь-Каширського району, де й народилися я з сестрою. Мама родом була з Східного Поділля. Польська влада та великий шовініст Кость Бернадський, який став головним ініиіатором концентраційного табору Береза Картузька, змусили батька протягом доби залишити Полісся, бо він не погоджувався виголошувати проповіді, читати Св. Свангеліє, викладати українським дітям релігію польською мовою. Тому з 1934 р. вони жсили на Волині”, - пригадує Любов Василів-Базюк [8].

У книзі “Дороги життя” авторка зауважує, що ніде вона себе так добре не почуває, як на Волині, серед рідних волинян у Видертій, Ветлях, Камені-Каширському, Ковелі, Білгородці, Золочівцях, Боголюбах, де пройшли їі дитячі роки. "Небагато спогадів залишилося з Видертої, але пам'ятаю, щзо я була дитиною природи. Мені подобалося бути на просторі, бігати по поліських лугах, лізти в болото, хоч дуже боялася п'явок. Ходила з сусідами до лісу, знала, де починаються багна та трясовиння, а в потічках мила ноги й дивилася, як жінки мочили коноплі та льон або прали білля" [24].

Життя у Видертій письменниця описує так: “Велике село, старовинна церква, хата, сад, город, поле та багато болотяних лугів і лісів. Парафіяни дотримувалися своїх звичаїв, пісень та особливої поліської народної культури. Люди вигодовували худобу, випасали овеџь, сіяли збіжжя, крім пшениці, яка тут не родить, садили картоплю, сіяли багато льону та конопель. Займалися ткацтвом, столярством та взагалі виробами з дерева. Селяни були побожні, ходили до иеркви, святкували всі свята, що випадали серед буднів, та дотримувалися строго посту. Батько, крім духовної праці, займався разом з мамою культурною та освітньою роботою. Передплачували 
пресу, книжки, дитячу літературу зі Львова, очевидно, иерковну літературу із Кремения та організували иерковний хор. До батькового приїзду в иеркві тільки співав один дяк. Хорового співу люди не чули. Мама співала в хорі, займалася з молоддю разом із сином дяка. Церковні та світські видання, які приносила пошта, читала наша родина, дякова та все село по черзі" [7].

Початкову освіту письменниця здобула в школах сіл Білогородка, нині Дубнівського району Рівненської області, та Боголюби, що поблизу Луцька. Восени 1940 р. сім'я переїхала на Холмщину. У 1941 р. Любов вступила до Холмської гімназії, у 1944 р. їхня родина через Лемківщину та Словаччину перебралася до Баварії, де опинилася в американській зоні окупованої Німеччини. У 1948 р. в місті Новий Ульм Любов закінчила навчання у філії Подебрадської гімназії і у червні 1948 р. зголосилася працювати у Канаді на текстильній фабриці. У Канаді вона закінчила торгівельне училище. В Торонтському університеті Любов Василів-Базюк отримала ступінь бакалавра, пізніше, у 48-річному віці, - ступінь магістра 3 бібліотечної справи та інформатики в Університеті Західного Онтаріо (Лондон, Канада). Упродовж 28 років працювала за фахом в установах міста Торонто.

Любов Василів-Базюк належить до “холмщаків", про яких вона писала, що вони “працьовиті, завзяті і незламні” [21]. Живучи в Канаді, вони ніколи не забували Батьківщини і знайшли у собі сили згуртуватися заради побудови омріяної вільної України, хоча й поза ії територіальними межами. "Міцно переживали депортацію автохтонних украйнців з Холмщини, Підляшия, бо між ними були також і наші рідні: в Тишівиях поляки замордували десятьох родичів, у Сагрині загинули родини Кутасів і Левчуків. Батько не міг спокійно про поляків говорити, адже, будучи священником, від них натерпівся. У Канаді важко пращював, підірвав своє здоров'я та після інсульту i другого інфаркту упокоївся 64-річним", - розповідає письменниця [8].

Любов Йосипівна виховувала своїх дітей, онуків у християнському, національному дусі. 3 листування 3 Іриною Калиновською (дослівно): “Мої діти $i$ внуки добре володіють українською мовою. Закінчили 11-річні суботні українські гімназії. Вдома розмовлясмо лише рідною мовою. Мене тішить, щзо 20-річна внучка Калина, студентка Кінгстонського університету, переклала англійською мовою мою книжку “У вирі тоталітарних режимів", яка має вийти друком наступного року. Син Андрій, за фахом музикант, приїзив в Україну, давав конщерти. Пожертвував отримані кочти на допомогу сиротам і дітям Чорнобиля. Донька Наталя, хірург-офтальмолог, відвідала Україну 1991 року в складі групи медиків США та Канади, обстежувала дітей Чорнобильської зони, досліджувала вплив радіачії на очі. Наталя хороший хірург, спеціалізується з хірургії сітківки ока. Пізніше моя донька і внуки об'іздили Україну /... / Вони на добрій дорозі”. Родина стала запорукою успішної письменницької, наукової, громадської діяльності Любові Йосипівни.

У 2003 р. Любов Василів-Базюк вперше після 60-річної розлуки з рідною землею прилетіла в Україну, відвідала близьку серцю Волинь. Кільце "Україна - Канада - Україна" нарешті зімкнулося. В Україні Любов Йосипівна відома своєю благочинністю. Вона дбає про будівництво українських церков, організовує збір коштів на відбудову Волинської богословської семінарії, засновує іменні стипендії для студентів, постійно надсилає примірники своїх книг до українських університетів, шкіл та бібліотек. За велику жертовну працю нагороджена орденами Св. Варвари, Св. Миколая, Св. Кирила і Мефодія.

Любов Василів-Базюк займається науковою діяльністю. Авторка написала десятки статей, присвячених дослідженням української історії (наприклад, [17], [20]), відвідала і виступала на багатьох конференціях, семінарах у Луцьку, Рівному, Дніпрі, Житомирі, Києві, Кременці, Львові, Хмельницькому, провела велику кількість зустрічей з громадськістю. Любов Йосипівна співпрацює з Науковим Товариством імені Шевченка (НТШ) у Канаді, Волинською та Рівненською богословськими академіями, товариством "Холмщина", постійно друкується у “Західноканадському збірнику”, "Бористені”, “Андріївському віснику”, “Свободі”, "Віснику”, “Духовній Ниві” тощо. Найбільш відомі ії доповіді в 2015 та 2016 рр. на конференціях НТШ у Канаді про перші релігійні книжки в Західній Україні [23], три важливі хвилі української імміграції в Канаді та зростання політичної діаспори [24]. 
Любов Василів-Базюк - патріотка свого краю, яка щиро вболіває за відновлення історичної правди. 3 листування з Іриною Калиновською (дослівно): “У Західньоканадійському Збірнику, у Номері 8 друкується моя довга стаття-відповідь польському письменнику Мокшицкому на відкритий лист до укр. письменників, щзо маємо перевиховати укр. народ Волині. Ніхто йому не відповів, мені знайомі прислали ию польську статтю, що вийшла в журналі "Меркуріюш" в польській мові, я йому відповіла в анг. мові, я не знаю літературноі писаної польської мови, розмовляю $і$ читаю. Переклала на укр. мову і тепер вона друкується 8 Едмонтоні з моєю поезією “Воскресіння”,". Йдеться про винищення поляками українців, яке письменниця пережила на прикладі своєї родини, про що відписала пану Мокшицькому у статті, разом з архівними даними, скільки людей, церков, було винищено.

Любов Йосипівна описує життя українців, особисто знайома з багатьма видатними українцями, цікавиться долями їхніх родин, аналізує архівні дані, бере участь у культурному й громадському житті українців. У творчому доробку письменниці десятки віршів, десять романів, перекладацький проєкт.

У книзі спогадів про своїх діда і батька "Вони служили церкві і рідному народу" (2003 р.). з допомогою історичних й документальних джерел висвітлено події церковного, громадського та суспільно-політичного життя Волині та Холмщини у 20-40 роки XX ст. [12]. Розповідь пронизана болем та тугою за Батьківщиною, бажанням бачити рідну Україну вільною, багатою, щасливими своїх земляків, свій народ.

Роман "У вирі тоталітарних режимів" (2005 р.) написаний під впливом реальних подій, пережитих українцями під час панування московського більшовизму, польського правління на українських землях та в роки німецько-гітлерівського режиму [13].

Роман "Не вір!" (2007 р.) присвячений відважним учасникам бою у Гурбах на Волині [14]. Вони пережили переслідування, не здалися, а любов до України пронесли через усе життя.

Книга "Україна на тернистому шляху до Духовного визволення" (2008 р.) написана під час поїздок письменниці до України [15]. Вона роздумує над причинами і наслідками історичних подій, ворожих впливів, які $є$ джерелом сучасного стану духовності земляків.

Книга “П'ять колосків” (2009р.) розкриває чорні сторінки нашої історії - голодоморугеноциду 20-30-х років минулого століття [16]. Читаючи цю історичну повість, кожен витре не одну гарячу сльозу, не одному читачеві вона зранить душу своїм болем і справедливим гнівом.

У романі “У горі та сльозах наша доля - геноциди в Україні” (2010р.) письменниця звертається до сумних подій в історії України, які весь цивілізований світ визнав геноцидом українського народу [18].

У книзі “Крізь пекло на землі!” (2012р.), в якій розповідається про життя українців, котрі пережили "пекло на землі", штучно створене загарбницькою московсько-комуністичною владою [19], читачі відкриють для себе численні невідомі криваві сторінки з історії рідного краю. В основі роману лежать історичні факти та спогади самої письменниці, а також ії земляків.

Книга “Дороги життя” (2015 р.) про життя Любові Василів-Базюк, про те, що вплинуло на iї характер та як формувалися іiі релігійні та політичні погляди, про дитинство на Волині, Другу світову війну, вимушений виїзд за кордон, пошуки місця проживання на чужій землі [23]. Випробування роблять авторку сильнішою, вона не втрачає віри в те, що колись повернеться на рідну землю.

У 2016 р. Любов Василів-Базюк взяла участь у перекладацькому проєкті разом 3 Володимиром Рожком. Перекладали писемне джерело від 1732 р. 3 польської на українську мову про ранню історію Почаївського монастиря “Монастир Скит” [26].

У романі "Новими стежками” (2018р.) йдеться про сучасне життя в Україні. Під час одинадцяти поїздок, по три місяці кожна, Любов Йосипівна спостерігала, як живуть українці [25]. Вона не тільки оглядала краєвиди, а й задумувалася над тим, як змінився український народ унаслідок життя під довгою окупацією.

Книга "В переможеній Німеччині” (2019р.) про вражаючі факти агресивної сталінської окупаційної політики у підкореній Німеччині та гостре соціально-політичне становище СРСР у 1939-1953 pp. [27]. 
Любов Василів-Базюк має багато творчих планів: “При Божій помочі, опіці та здоров’ї надалі писатиму. Хочу залишити новим поколінням правдиве висвітлення історичних подій та визначити ставлення до нас сусідів 3 північного-сходу і заходу" [8].

Висновки та перспективи подальших досліджень. Любов Василів-Базюк - приклад незламної, сильної українки, патріотки, яка, опинившись у канадській еміграції, зуміла залишитися вірною своєму народу: "Україна тільки одна, це наша одинока Батьківщина, нас Бог залишив при житті, щоб ми для неї працювали та для неї жили. Я не тільки живу для Волині та Холмщини, де я народилася та жила, а для всієї України" [25]. Історія рідного краю відображена не тільки в життєписі волинянки в непрості часи, які пережила Україна, а й в ії романах, віршах, наукових стаття, дописах. Проаналізувавши науковий та творчий доробок письменниці, слід зазначити, що публікації Любові Йосипівни присвячені трагічним сторінкам історії України та засновані на спогадах письменниці, очевидців та документальних матеріалах.

1. Babiychuk, Tetyana. 2016. "Propahanda zasobamy mediaosvity romanu "Kriz peklo na zemli" Lyubovi Vasyliv-Bazyuk". Psykholoho-pedahohichni nauky 4: 7-10.

2. Kalynovska, Iryna and Elina Koliada. 2020. "Obraz ukrayinskoho suspilstva v kanadskiy literaturi". Kanadoznavstvo: suspilni ta osvitni viziyi: kolektyvna monohrafiya. Lutsk: Vezha-Druk 96-116.

3. Kalynovska, Iryna, Elina Koliada, Natalia Odarchuk. 2019. "Ukrayinsko-kanadski osvitni zviazky (na prykladi doslidnytskoho proyektu)". Naukovyy visnyk SNU imeni Lesi Ukrayinky. Filolohichni nauky 10(394): 61-65.

4. Kostenko, Tetyana. 2010. "Pysmennytsya z diaspory Lyubov Vasyliv-Bazyuk: 'Dvokh svyatykh yepyskopiv z nashoyi rodyny zamorduvaly bil'shovyky!'”. Dzerkalo tyzhnya. 22 zhovtnya. https://zn.ua/ukr/ART/ pismennitsya_z_diaspori_lyubov_vasiliv-bazyuk_dvoh_svyatih_episkopiv_z_nashoyi_rodini_zamorduvali_ bi.html

5. Kovelska miska himnaziya. 2019. "Z lyubovyu do otchoho krayu”. 24 veresnya. http://kovelgim.at.ua/news/z ljubov ju do otchogo kraju/2019-09-24-1182

6. Odarchuk, Natalia, Elina Koliada, Iryna Kalynovska. 2019. "Obraz ukrayinskoho pravoslavnoho svyashchennyka v tvorakh Lyubovi Vasyliv-Bazyuk". Visnyk Mariupolskoho derzhavnoho universytetu. Seriya Filolohiya 21: 67-74. DOI 10.34079/2226-3055-2019-12-21-67-74.

7. Panchenko, Oleksandr. 2019. "Volyn, Poltavshchyna, Kanada i mentalnyi ukrayinskyi khutir.... Lyubov Vasyliv-Bazyuk: zhyttya i tvorchist na ukrayinskykh terezakh: knyhy, lysty, spomyny, refleksiyi..." Den. Shchodenna vseukrayinska hazeta. 25 veresnya. http://incognita.day.kyiv.ua/volin,-poltavshhina,-kanada-jmentalnij-ukrayinskij-xutir\%E2\%80\%A6.-lyubov-vasiliv-bazyuk-zhittya-j-tvorchist-na-ukrayinskix-terezaxknigi,-listi,-spomini,-refleksiyi\%E2\%80\%A6.html

8. Smilka, Roman. 2011. "Vid vas, batky i materi zalezhyt, natsionalne vykhovannya ta syla molodoho pokolinnya!". Narodna pravda. 10 sichnya. https://narodna.pravda.com.ua/history/4d2ad2228ae60/

9. SNU. 2019. "Lyubov do otchogo krayu". https://eenu.edu.ua/uk/articles/lyubov-do-otchogo-krayu

10. SNU. 2019. "Z Volyni do Kanady: yuviley pochesnoho profesora universytetu". https://eenu.edu.ua/ uk/articles/z-volini-do-kanadi-yuviley-pochesnogo-profesora-universitetu

11. Trafyak, Mykhaylo. 2017. "Ukrayinska literatura v Kanadi na suchasnomu etapi. Proza chetvertoho periodu". Novyy shlyakh. Ukrayinski visti vid 9 sichnya. https:/www.newpathway.ca/

12. Vasyliv-Bazyuk, Lyubov. 2003. Vony sluzhyly tserkvi i ukrayins'komu narodovi: spohady pro dida i batka. Lviv: Spalom.

13. Vasyliv-Bazyuk, Lyubov. 2005. U vyri totalitarnykh rezhymiv. Chernivtsi: Bukrek.

14. Vasyliv-Bazyuk, Lyubov. 2007. Ne vir! Chernivtsi: Bukrek.

15. Vasyliv-Bazyuk, Lyubov. 2008. Ukrayina na ternystomu shlyakhu do dukhovnoho vyzvolennya. Chernivtsi: Bukrek.

16. Vasyliv-Bazyuk, Lyubov. 2009. Piat koloskiv. Chernivtsi: Bukrek.

17. Vasyliv-Bazyuk, Lyubov. 2010. "Zhyttya materiv i zhinok v istorychniy chastyni Volyni, Kholmshchyni i Pidlyashshi”. Zbirnyk materialiv Mizhnarodnoyi naukovo-praktychnoyi konferentsiyi z nahody yuvileyu 60richchya zasnuvannya Instytutu doslidiv Volyni ta Tovarystva "Volyn"” u Vinnipezi. Luts'k: Volynska dukhovna seminariya 69-81.

18. Vasyliv-Bazyuk, Lyubov. 2010. U hori ta slozakh nasha dolya-henotsydy v Ukrayini. Chernivtsi: Bukrek.

19. Vasyliv-Bazyuk, Lyubov. 2012. Kriz peklo na zemli. Chernivtsi: Bukrek.

20. Vasyliv-Bazyuk, Lyubov. 2013. "Akademiya v pamiat Tarasa Shevchenka v Kholmi - zasluha profesora Serhiya Biloho". Andriyivskyi visnyk: Istoryko-bohoslovskyy shchorichnyy zhurnal Rivnenskoyi dukhovnoyi seminariyi. Rivne 2: 206-210.

21. Vasyliv-Bazyuk, Lyubov. 2014. "Hirka dolya kholmshchakiv i pidlyashukiv". Vid deportatsiyi do deportatsiyi. Suspil'no-politychne zhyttya kholmsko-pidlyaskykh ukrayintsiv (1915-1947). Chernivtsi: Bukrek 311-317.

22. Vasyliv-Bazyuk, Lyubov. 2015. "Pershi relihiyni knyzhky v Zakhidniy Ukrayini ta yikh velyke znachennya dlya Ukrayinskoho Narodu". Video vystupu. https://www.youtube.com/watch?v=wNu_USEG160 
23. Vasyliv-Bazyuk, Lyubov. 2015. Dorohy zhyttya. Chernivtsi: Bukrek.

24. Vasyliv-Bazyuk, Lyubov. 2016. "Try khvyli ukrayinskoyi emihratsiyi v Kanadi ta zrostannya politychnoyi diaspory”. Novyy shlyakh. Ukrayinski visti vid 12 kvitnya. Chastyna 2. https://www.newpathway.ca/

25. Vasyliv-Bazyuk, Lyubov. 2018. Novymy stezhkamy. Chernivtsi: Bukrek.

26. Vasyliv-Bazyuk, Lyubov and Volodymyr Rozhko. 2014. Monastyr Skyt. Lutsk: Volynska oblasna drukarnya.

27. Vasyliv-Bazyuk, Lyubov; Slobodyanyuk, Petro. 2019. V peremozheniy Nimechchyni. Vinnytsya.

Плешкова Ольга, Калиновская Ирина, Коляда Элина. История родного края сквозь призму жизненного и творческого пути украинско-канадской писательницы Любови Васильев-Базюк. Статья посвящена анализу жизненного и творческого пути Любови Иосифовны Васильев-Базюк. Имя несломленной женщины, родом из волынского села, хорошо известно за пределами Украины. Во время Второй мировой войны она вынуждена была покинуть родную землю, чтобы через десятилетия не раз вернуться сюда, доказав, что сердце ее принадлежит отечеству. Она является примером сильной украинки, сумевшей остаться верной своему народу.

Сегодня Любовь Васильев-Базюк - известная писательница, ученый, благотворительница, настоящая патриотка, которая, проживая за океаном, в Торонто, не теряет связи с Волынью. Она заботится о строительстве украинских церквей, организовывает сбор средств на восстановление Волынской богословской семинарии, основывает именные стипендии для студентов, пишет книги о событиях, которые близки для миллионов украинцев.

В творческом и научном наследии Любови Васильев-Базюк, почетного профессора Волынского национального университета имени Леси Украинки, имеются десятки научных статей, стихов, десять исторических романов, написанных на основе документальных материалов, воспоминаний собственных и очевидцев. Ее научные статьи и романы посвящены трагическим событиям в истории Украины и Волыни в частности. Писательница также освещает важные современные политические события и социальные проблемы жизни украинцев как в Украине, так и в эмиграции. Она пишет о своей жизни, о том, что повлияло на ее характер и как формировались ее религиозные и политические убеждения. Любовь Васильев-Базюк постоянно высылает экземпляры своих книг в украинские университеты, колледжи, библиотеки.

За большой жертвенный труд Любовь Васильев-Базюк награждена орденами Св. Николая, Св. Варвары, Св. Кирилла и Мефодия.

В 2019-2020 гг. жизненный и творческий путь Любови Васильев-Базюк изучали ученые Волынского национального университета имени Леси Украинки и учителя Ковельской городской гимназии имени Елены Пчилки в рамках грантового исследовательского проекта при поддержке Канадского института украинских студий (Мемориальный Фонд имени Петра Черного). Был проведен ряд творческих встреч, круглых столов, семинаров, научно-художественных мероприятий.

Ключевые слова: Украина, Канада, Волынь, писательница, украинско-канадские исследования.

Plieshkova Olha, Kalynovska Iryna, Koliada Elina. The History of the Native Land through the Prism of the Ukrainian-Canadian Writer Lyubov Vasyliv-Bazyuk's Life and Works. The article is devoted to the analysis of Lyubov Vasyliv-Bazyuk's life and works. The name of an unbroken woman, Volhynian by birth, is well known outside Ukraine. During World War II, she was forced to leave her native land, but she would return there more than once in decades, proving that her heart belongs to her fatherland. She is an example of a strong Ukrainian woman who has managed to remain faithful to her people.

Today Lyubov Vasyliv-Bazyuk is a well-known writer, scholar, philanthropist, and a real patriot who, living overseas, in Toronto, does not lose touch with Volhynia. She takes care of the construction of Ukrainian churches, organizes fundraising for the restoration of the Volyn Theological Seminary, establishes scholarships for students, and writes books about events that are familiar to millions of Ukrainians.

The creative and scientific heritage of Lyubov Vasyliv-Bazyuk, Honorary Professor of the Lesya Ukrainka Volyn National University, contains dozens of research articles, poems, and ten historical novels written on the basis of documentary materials, firsthand testimonies and her own personal memories. Her research articles and historical novels are devoted to the tragic events in the history of Ukraine and Volhynia in particular. The writer also covers important contemporary political events and social problems of Ukrainians both in Ukraine and abroad. She writes about her life and factors that influenced the formation of her character and her religious and political beliefs. Lyubov Vasyliv-Bazyuk sends copies of her books to Ukrainian universities, colleges, and libraries.

For her great sacrificial work, Lyubov Vasyliv-Bazyuk was awarded the Orders of St. Nicholas, St. Barbara, and St. Cyril and Methodius.

In 2019-2020 the life and works of Lyubov Vasyliv-Bazyuk were studied by scholars of the Lesya Ukrainka Volyn National University and teachers of the Olena Pchilka Kovel City Gymnasium as part of a research project supported by the Canadian Institute of Ukrainian Studies (Petro Czornyj Memorial Endowment Fund). A number of round-table discussions, seminars, scientific and artistic events were held.

Key words: Ukraine, Canada, Volhynia, writer, Ukrainian-Canadian studies. 